\title{
Liver receptor homologue-1 regulates gonadotrope function
}

\author{
Weiming Zheng, Jingying Yang, Qiaorong Jiang, Zhibin He and Lisa M Halvorson \\ Division of Reproductive Endocrinology, Department of Obstetrics and Gynecology, University of Texas Southwestern Medical Center, Dallas, Texas 75390-9032, USA
}

(Requests for offprints should be addressed to L M Halvorson; Email: lisa.halvorson@ utsouthwestern.edu)

\begin{abstract}
Over the past decade, substantial advances have been made in our understanding of the transcription factors which regulate gene expression in gonadotropes. One of the most important of these factors, steroidogenic factor-1 (SF-1; NR5A1) is critical for gonadotropin and GnRH-receptor expression. Interestingly, a closely related nuclear hormone receptor, liver receptor homologue-1 (LRH-1; NR5A2) has recently been detected in the anterior pituitary gland; however, its functional significance in this tissue has not been investigated. For the experiments reported here, we hypothesized that $\mathrm{LRH}-1$ plays a previously unrecognized role in gonadotrope physiology. Towards this end, we first demonstrate $\mathrm{LRH}-$ 1 mRNA and protein expression in both primary pituitary cells and gonadotrope-derived cell lines. We next show that $\mathrm{LRH}-1$ stimulates promoter activity of the $\mathrm{GnRH}$-receptor and gonadotropin subunit genes. Within the $L H \beta$ gene, this response appears to be mediated by DNA-binding and transactivation through previously characterized SF-1 ciselements. To our knowledge, this is the first report demonstrating a functional role for LRH-1 in the gonadotrope population of the anterior pituitary gland.
\end{abstract}

Journal of Molecular Endocrinology (2007) 38, 207-219

\section{Introduction}

Normal reproductive function requires precise quantitative and temporal regulation of gonadotropin biosynthesis by the gonadotrope subpopulation of the anterior pituitary gland. Over the past decade, studies have identified a complex array of transcription factors and associated DNA-regulatory elements which mediate basal, tissue-specific, and hormonally responsive expression of the gonadotropin subunits and the gonadotropin-releasing hormone (GnRH)-receptor gene (Barnhart \& Mellon 1994, Haisenleder et al. 1996, Lee et al. 1996, Halvorson et al. 1998, Tremblay \& Drouin 1999, Kaiser et al. 2000, Keri et al. 2000, Huang et al. 2001, Quirk et al. 2001, Norwitz et al. 2002, Jacobs et al. 2003, Jeong et al. 2004).

One of these transcription factors, the orphan nuclear receptor steroidogenic factor-1 (SF-1; NR5A1), has been implicated in the regulation of a wide variety of genes which play a role in steroidogenesis, sexual differentiation, and adult reproductive function (Luo et al. 1994, Sadovsky et al. 1995). Within the pituitary gland, SF-1 is selectively expressed in the gonadotrope subpopulation of the pituitary gland, as well as in the ventromedial hypothalamus, gonads, and adrenal gland (Ikeda et al. 1995). SF-1 binds as a monomer to a consensus sequence, known as an Ad4 or gonadotrope-specific element (GSE), which resembles a nuclear receptor half-site (Horn et al. 1992). Functionally important GSEs have been identified in the common $\alpha$-subunit, luteinizing hormone
(LH) $\beta$-subunit and GnRH-receptor (GnRH-R) gene promoters (Halvorson et al. 1996, Keri \& Nilson 1996, Pincas et al. 2001, Fowkes et al. 2003).

Liver receptor homologue-1 (LRH-1; NR5A2) - also known as $\alpha$-fetoprotein transcription factor (FTF), CYP7A (cholesterol $7 \alpha$-hydroxylase) promoter binding factor $(\mathrm{CPF})$, and human $\mathrm{B}-1$ binding factor $(\mathrm{hB} 1 \mathrm{~F})$ - is closely related to SF-1 based on similarities in amino acid sequence and protein structure. As suggested by its name, LRH-1 was initially discovered in the mouse liver and subsequently has been described as a key regulator of bile acid metabolism and cholesterol homeostasis (Goodwin et al. 2000, Lu et al. 2000). More recent studies have revealed LRH-1 expression in the adrenal gland, adipocytes, pancreas, and gut (Sirianni et al. 2002, Clyne et al. 2004). Especially, high levels of LRH-1 mRNA are present in the ovary and testis (Falender $e t a l$. 2003. Hinshelwood et al. 2003, Pezzi et al. 2004, Lambard et al. 2005). LRH-1, like SF-1, has been demonstrated to stimulate expression of genes which encode steroidogenic enzymes, including the StAR, CYP11A1 and the aromatase genes (Sirianni et al. 2002, Clyne et al. 2004). The predominant form of LRH-1 protein is approximately $64 \mathrm{kDa}$ in size; however, multiple transcriptional and post-transcriptional variants have been described which result in products spanning 54-64 kDa. The expression of these variants shows both species and tissue specificity (Galarneau et al. 1996, Li et al. 1998, Goodwin et al. 2000, Wang et al. 2001, Falender et al. 2003, Peng et al. 2003, Kudo \& Sutou 2006). In a recent report, LRH-1 mRNA 
expression was detected in the pituitary gland; however, its function in this tissue has not been elucidated (Falender et al. 2003). In the studies reported here, we present evidence that LRH-1 plays a role in gonadotrope physiology, with a focus on the LH $\beta$ gonadotropin gene.

\section{Materials and methods}

\section{Reverse transcription PCR (RT-PCR)}

Total RNA was isolated from cell lines, rat pituitary tissue or mouse liver using the Qiagen RNeasy Mini Kit according to the manufacturer's instructions (Qiagen). The immortalized mouse gonadotrope cell lines, L $\beta$ T2 and $\alpha \mathrm{T} 3-1$, were generously provided by P L Mellon (University of California, San Diego, CA, USA). Pituitary tissue samples were homogenized by trituration first through an 18-gauge and then through a 21-gauge syringe needle in RLT lysis buffer containing $10 \mu \mathrm{l} / \mathrm{ml} \beta$-mercaptoethanol (Sigma-Aldrich Corp.). Tissue culture cell-samples were washed with PBS and harvested by scraping in RLT lysis buffer. Cell and tissue samples were further homogenized by centrifugation through Qiashredder spin columns (Qiagen) and the resulting samples were then subjected to the RNA isolation process. The concentration of total RNA in the final samples was determined by measurement on a BioRad SmartSpec 3000 spectrophotometer (Bio-Rad Laboratories).

Total RNA $(1 \mu \mathrm{g})$ was reverse transcribed at $37^{\circ} \mathrm{C}$ for $1 \mathrm{~h}$ in the presence of $500 \mathrm{ng}$ of random hexamers (Invitrogen) and 10 units AMV Reverse Transcriptase (Promega) in buffer containing $5 \mathrm{mM} \mathrm{MgCl} 2,1 \times$ PCR buffer, $1 \mathrm{mM}$ dNTP, and 20 units RNase Out (Invitrogen). PCR was performed on $5 \mu \mathrm{l}$ of the resulting cDNA sample in the presence of $2 \mathrm{mM} \mathrm{MgCl}_{2}$ and $2 \cdot 5$ units Taq polymerase (Promega). PCR conditions were as follows: $95^{\circ} \mathrm{C} \times 3 \mathrm{~min}, 35$ cycles $\times\left(95^{\circ} \mathrm{C}, 30 \mathrm{~s} ; 55^{\circ} \mathrm{C}\right.$, $30 \mathrm{~s} ; 72^{\circ} \mathrm{C}, 60 \mathrm{~s}$ ), and $72^{\circ} \mathrm{C} \times 5 \mathrm{~min}$. The product was resolved by $1 \%$ agarose gel electrophoresis. Primer pairs for mouse LRH-1 samples were $5^{\prime}$-GAAGCTGCTTCAAAACTGC-3' (sense) and 5'-CCGTTCACGTGCTTATAGTAC-3' (antisense). The rat LRH-1 primer sequences were $5^{\prime}$-TGAAGCTGCTTCAGAACTGC-3' (sense) and 5'-CCATTCACGTGCTTGTAGTAC-3' (antisense). These primers produce a predicted product size of $447 \mathrm{bp}$ (mouse) or $448 \mathrm{bp}$ (rat) which spans the ligand-binding domain.

\section{Western blot analysis}

Nuclear extracts were obtained using the NE-PER extraction reagents supplemented with protease and phosphatase inhibitors and quantified by BCA assay
(Pierce Biotechnology, Inc., Rockford, IL, USA). Proteins were separated using $12 \%$ SDS-PAGE and transferred to PVDF membrane. After overnight blocking, the membranes were incubated with the primary antibody followed by a horseradish peroxidaseconjugated anti-rabbit IgG secondary antibody. After washing, the bound secondary antibody was visualized using enhanced chemiluminescent (ECL) western blot detection reagents (Amersham Biosciences). The SF-1 antibody was obtained through Upstate Biotechnologies (Charlottesville, VA, USA). Two LRH-1/FTF antibodies were kindly provided by L Belanger (Laval University Cancer Research Center, Quebec, Canada; Galarneau et al. 1996). The antibody designated LRH-1 Ab1 was raised in rabbit against rat amino acid \#142-156. A second LRH-1/FTF antiserum, LRH-1 Ab2 was directed against rat amino acid positions \#242-560 and was unsuccessful on Western but was effective on electrophoretic mobility shift assay (EMSA). Both antibodies are cross reactive with mouse.

\section{Transient transfection of cell lines}

Green monkey kidney fibroblast (CV-1) and mouse gonadotrope-derived cells (L $\beta \mathrm{T} 2$ ) were maintained in monolayer culture in Dulbecco's modified Eagle's medium supplemented with $10 \%(\mathrm{v} / \mathrm{v})$ certified fetal calf serum and $1 \%(\mathrm{v} / \mathrm{v})$ penicillin/streptomycin at $37^{\circ} \mathrm{C}$ in humidified $5 \% \mathrm{CO}_{2} / 95 \%$ air. Cells were transfected at approximately $50-80 \%$ confluence in 12-well plates using the calcium phosphate precipitation method (CV-1 cells) or Lipofectamine Reagent (L $\beta T 2$ cells; Invitrogen). CV-1 cells received $0 \cdot 4 \mu \mathrm{g} /$ well of reporter vector and $0 \cdot 1 \mu \mathrm{g} /$ well of expression vector or as indicated in the dose-response experiments. L $\beta \mathrm{T} 2$ cells received $0.2 \mu \mathrm{g} /$ well of reporter vector and $0 \cdot 3 \mu \mathrm{g} /$ well of expression vector. Cotransfection with a pSV- $\beta$-galactosidase plasmid allowed correction for differences in transfection efficiency between wells in all experiments. Cells were harvested approximately $48 \mathrm{~h}$ following transfection and the cell extracts analyzed for luciferase activity as previously described and for $\beta$-galactosidase activity using the Galacto-Light assay system (Applied Biosystems, Foster City, CA, USA; de Wet et al. 1987). Luciferase activity was normalized to the level of $\beta$-galactosidase activity and results calculated as fold-change relative to expression in the control wells. Data are shown as the mean \pm s.E.M. from 3 to 7 independent experiments with each point tested in triplicate.

\section{Plasmids used in transfection studies}

The rat $-207 /+5 \mathrm{LH} \beta$, rat $-2000 /+1709 \mathrm{FSH} \beta$, and mouse $-1164 /+62$ GnRH-R constructs consist of the 
corresponding cDNA subcloned into the luciferase reporter gene, pXP2 (Nordeen 1988; constructs kindly provided by U B Kaiser, Brigham and Women's Hospital, Boston, MA, USA). The $\alpha$-luciferase construct spans region $-846 /+44$ of the human glycoprotein $\alpha$-subunit inserted into pA3-luc luciferase expression vector (gift of J L Jameson, Northwestern University School of Medicine, Chicago, IL, USA). The sequence of the mutated LH $\beta$ gene promoter constructs can be found in a previous report by Halvorson et al. (1998).

The LRH-1 expression vector contains $1.7 \mathrm{~kb}$ of the mouse LRH-1 cDNA subcloned into pcDNA3 $1 /$ Amp (Invitrogen; cDNA provided by D J Mangelsdorf, University of Texas Southwestern Medical Center, Dallas, TX, USA). The SF-1 expression vectors contain $2 \cdot 1 \mathrm{~kb}$ of the mouse SF-1 cDNA driven by the cytomegalovirus promoter in the pcDNA3.1 expression vector (SF-1 cDNA provided by K L Parker, University of Texas Southwestern Medical Center, Dallas, TX, USA).

\section{Electrophoretic mobility shift assay (EMSA)}

Double-stranded oligonucleotide probes were created by T4 polynucleotide kinase end-labeling with $\left[\gamma_{-}^{-32} \mathrm{P}\right]$-ATP followed by purification over a Quick Spin G-25 Sephadex Column (Roche Applied Science). The nucleotide sequence of the rat LH $\beta$ gene promoter is based on sequencing data available at GenBank accession number AF020505. The sense strands for the oligonucleotides containing the $3^{\prime} \mathrm{GSE}$ and $5^{\prime} \mathrm{GSE}$ regions were respectively $5^{\prime}$-TGCTTAGTGGCCTTGCCACCCCCA- $3^{\prime}$ and $5^{\prime}$-TCCTTTCTGACCTTGTCTGTCT- ${ }^{\prime}$.

Nuclear proteins were isolated as described for Western blot analysis. Where indicated, $1 \mu \mathrm{l}$ of antisera was added to the protein samples $20 \mathrm{~min}$ prior to the addition of labeled probe (see section describing Western Blot for description of antibodies). Protein-DNA complexes were resolved on a $5 \%$ non-denaturing polyacrylamide gel in $0.5 \mathrm{X}$ Tris-borate-EDTA buffer and subjected to autoradiography. In vitro translated mouse SF-1 and LRH-1 were generated using the TNT Coupled Reticulocyte Lysate System (Promega).

\section{Statistical analysis}

Statistical calculations were performed using the SigmaStat statistical software package (SPSS Science, Chicago, IL, USA). Data were analyzed for normality followed by calculation of ANOVA or the Kruskal-Wallis ANOVA on ranks for non-parametric data. The Tukey method was utilized for post hoc comparison, except for experiments with different sample sizes in which case the Dunn's test was employed. Statistical significance was set at $P<0 \cdot 05$.

\section{Results}

\section{LRH-1 mRNA is expressed in the pituitary gland and in gonadotrope cell lines}

Reverse-transcription PCR was used to determine the presence of LRH-1 transcripts (Fig. 1). Bands of the appropriate size were detected in both the anterior and the posterior pituitary glands from rats (Fig. 1A), as well as the two mouse gonadotrope cell lines, $\alpha \mathrm{T} 3-1$ and L $\beta \mathrm{T} 2$ (Fig. 1B). A plasmid encoding LRH-1 and mouse liver were used as positive controls (Fig. 1B). Products obtained from primary pituitary cells and the $\alpha \mathrm{T} 3$ and L $\beta \mathrm{T} 2$ cell lines were confirmed to be LRH-1 by sequence analysis.

\section{LRH-1 protein is expressed in the anterior pituitary gland and in gonadotrope cell lines}

LRH-1 protein was detected in gonadotrope cell lines and the pituitary gland using the LRH-1 Ab1 antibody in Western analysis (Fig. 2). As shown in Fig. 2A, in vitro translated LRH-1 produced a band of the predicted size (approximately $64 \mathrm{kDa}$; lane 2). No distinct band was

A

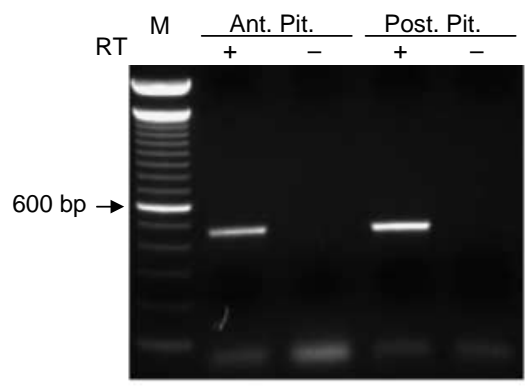

B

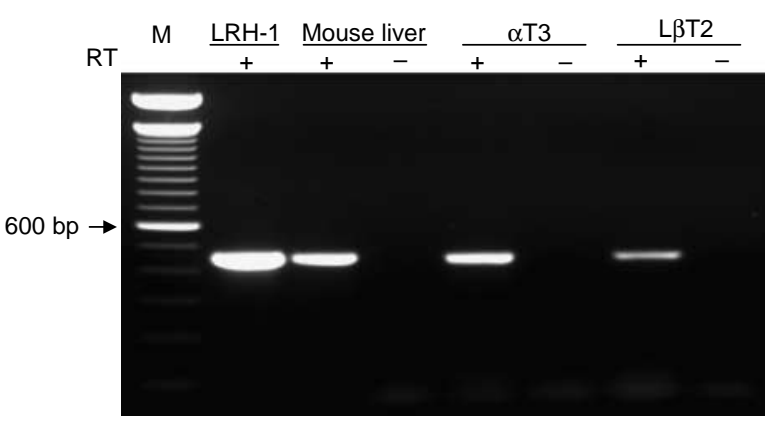

Figure 1 Expression of LRH-1 mRNA in the pituitary gland and in gonadotrope cell lines as analyzed by reverse transcription polymerase chain reaction (RT-PCR). (A) Rat anterior pituitary (Ant. Pit.) and posterior pituitary (Post. Pit.) were tested in the presence $(+)$ or absence $(-)$ of reverse transcriptase (RT).

(B) LRH-1 plasmid, mouse liver, $\alpha$ T3-1 cells and L $\beta$ T2 cells were tested in the presence $(+)$ or absence $(-)$ of reverse transcriptase. M, size markers. 

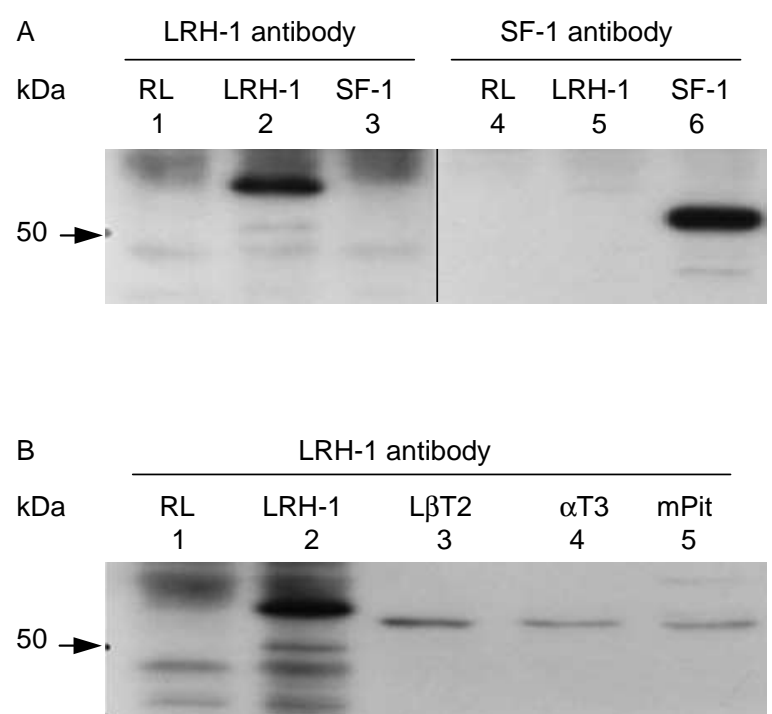

Figure 2 Expression of $\mathrm{LRH}-1$ protein in the anterior pituitary gland and in gonadotrope cell lines by Western blot analysis. (A) LRH-1 antibody was used to detect $L R H-1$ protein in a reticulocyte lysate $(R L)$ preparation of in vitro translated LRH-1 (lanes 1-3). Detection of in vitro translated SF-1 was done by an SF-1-specific antibody (lanes 4-6). $\mathrm{LRH}-1$ has a predicted size of approximately $64 \mathrm{kDa}$ and SF-1 has a predicted size of $54 \mathrm{kDa}$. Note the ability of the antibodies to distinguish between $\mathrm{LRH}-1$ and SF-1. (B) LRH-1 immunoreactivity in the gonadotrope-derived cell lines L $\beta$ T2 and $\alpha$ T3-1 (lanes 3 and 4 ) as well as in primary mouse anterior pituitary cells ( $\mathrm{mPit}$; lane 5 ).

detected in the reticulocyte lysate (RL) alone or in vitro translated SF-1 lanes (lanes 1 and 3), demonstrating the desired specificity of this antibody. In the right panel, an SF-1 antibody was used to demonstrate that SF-1 runs as a slightly smaller product $(54 \mathrm{kDa})$ on Western blot, as would be predicted. Appropriately, this antibody detects SF-1 in an in vitro translated SF-1 preparation (lane 6) but does not detect any proteins in an in vitro LRH-1 preparation (lane 5).

The presence of endogenous LRH-1 in mouse pituitary cells and gonadotrope cell lines is shown in Fig. 2B. In order to allow clear visualization of the endogenous protein, this Western gel was exposed for a longer time than in 2A. The multiple proteins observed in the RL and LRH-1 lanes (lanes 1 and 2) were also present in Fig. 2A. The band at approximately $54 \mathrm{kDa}$ in the lane 2 likely represents a post-transcriptional splice variant as previously described by other investigators. The slightly greater mobility observed for endogenous LRH-1 relative to the in vitro translated product is also consistent with the multiple splice variants reported for LRH-1 (Galarneau et al. 1996, Kudo \& Sutou 2006).

\section{LRH-1 stimulates gonadotrope-specific gene expression}

Having demonstrated the presence of LRH-1 transcripts and protein in gonadotropes, we next wished to determine whether LRH-1 modulates expression of the gonadotropin subunit genes or the GnRH-R gene (Fig. 3A). For these experiments, we utilized a transient transfection approach. When introduced into the fibroblast cell line, CV-1, LRH-1 significantly increased the promoter activity of the common $\alpha$-, LH $\beta$, FSH $\beta$, and GnRH-R genes with the largest response observed with the LH $\beta$ construct (15fold; $P<0.001)$. LRH-1 did not significantly alter expression of the corresponding empty expression vectors (data not shown).

As SF-1, which is closely related to LRH-1, is known to be an important regulator of LH $\beta$ gene expression, we compared the effects of LRH-1 and SF-1 on this gene promoter (Fig. 3B). In an attempt to provide relatively equal expression of the two proteins, we utilized SF-1 and LRH-1 cDNAs in the same expression construct (pcDNA 3.1). The addition of LRH-1 induced an 18 -fold increase in $\mathrm{LH} \beta$ gene promoter activity, while SF-1 stimulated expression by 37-fold $(P<0 \cdot 001$ for LRH-1 and SF-1 vs control; $P<0 \cdot 001$ for LRH-1 vs SF-1).

Prior studies by our group and others have identified two regions in the $L H \beta$ gene, which are critical for the ability of SF-1 to increase promoter activity of this gene. These sites have been designated gonadotrope-specific elements (5'-GSE and 3'-GSE; Halvorson et al. 1998). As LRH-1 has been shown to have a similar consensus DNA-binding sequence, we postulated that LRH-1 stimulation of the LH $\beta$ gene promoter may also be mediated via one or both of the GSEs (Solomon et al. 2005). Mutations in either of these previously described GSE sites markedly diminished LRH-1-responsiveness (Fig. 3C). Mutation of both GSE sites eliminated LRH1-mediated stimulation to the level of the empty expression vector, $\mathrm{pXP2}$. These data support a role for each of the GSE sites in mediating the LRH-1 response.

The ability of LRH- 1 to stimulate LH $\beta$ promoter gene expression was confirmed in the L $\beta \mathrm{T} 2$ gonadotrope cell line (Fig. 3D). As these cells express both LRH-1 and SF1 , overexpression studies routinely demonstrate markedly diminished responses. Nevertheless, the addition of either LRH-1 or SF-1 increased LH $\beta$ gene promoter activity. The small LRH-1 effect $(1 \cdot 4$-fold) was highly reproducible and significant at the $P<0 \cdot 001$ level. Taken as a whole, these results strongly imply that LRH1 plays a role in mediating gonadotrope-specific gene expression.

\section{Dose-response of LRH-1 vs SF-1 on rat LH $\beta$ gene promoter activity}

A dose-response experiment was performed in CV-1 cells in order to further assess the effectiveness of LRH1 relative to SF- 1 in the stimulation of rat $\operatorname{LH} \beta$ gene promoter activity. LRH-1 achieved a maximal 30-fold increase in promoter-reporter expression at 
A

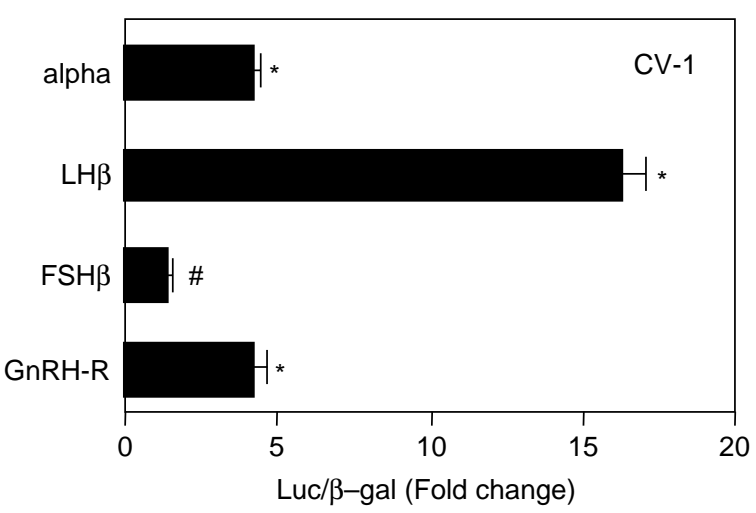

B

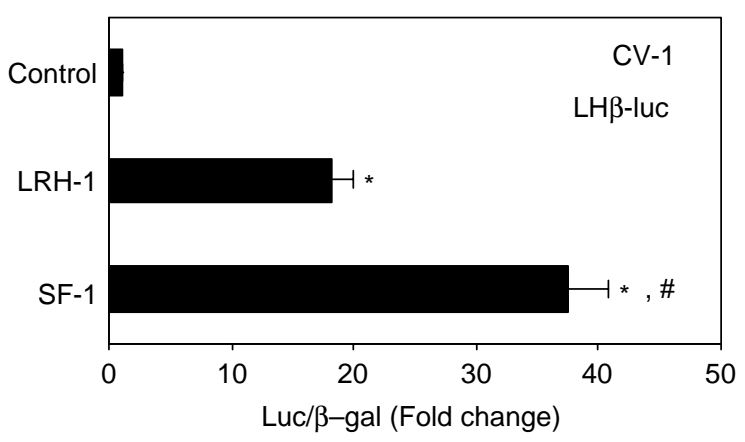

C

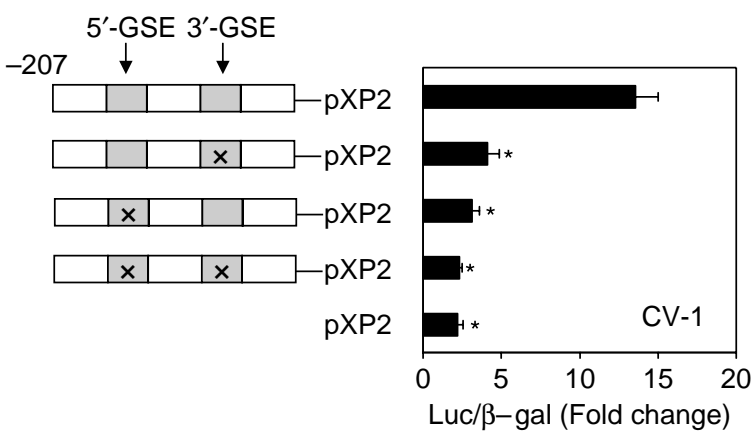

D

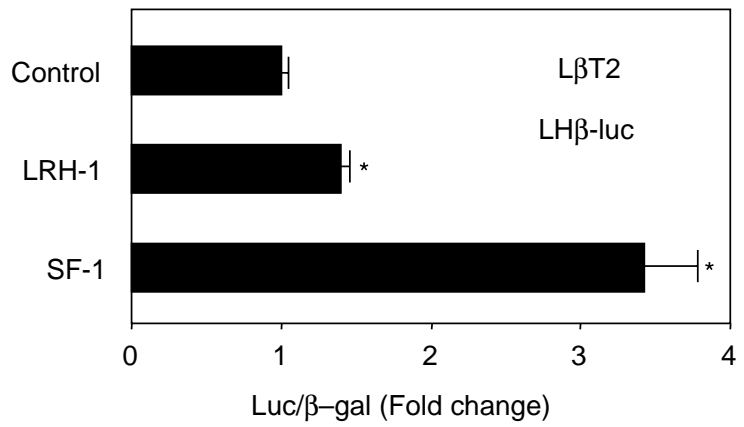

10-30 ng/well of plasmid (Fig. 4A), while the SF-1 vector stimulated the $\mathrm{LH} \beta$ promoter up to 200 -fold at $3 \mathrm{ng} /$ well (Fig. 4B). These results suggest that LRH-1 is an effective, but less robust, activator of $\mathrm{LH} \beta$ gene promoter activity as compared with SF-1, at least as measured in this in vitro system.

\section{Combined effect of LRH-1 and SF-1 on LH $\beta$ gene promoter activity}

Cotransfection experiments were conducted to determine the effect of addition of both LRH-1 and SF-1 on LH $\beta$ promoter activity. As shown in Fig. 4C, the combined stimulatory effect of SF-1 and LRH-1 on the LH $\beta$ promoter activity was generally higher than the effect of either SF-1 or LRH-1 alone. When larger amounts of LRH-1 plasmid were transfected, their combined effect increased significantly. These data suggest an additive character of SF-1 and LRH-1 effect on $\mathrm{LH} \beta$ promoter activity.

\section{LRH-1 binds to the LH $\beta$ gene promoter}

As demonstrated in Fig. 3C, the ability of LRH-1 to functionally increase LH $\beta$ gene promoter activity was conferred by both of the GSE sites. We next wished to determine whether LRH-1 bound directly to these DNA-regulatory regions. EMSA was used to analyze the ability of in vitro translated LRH-1 to bind to a nucleotide probe containing the $3^{\prime}$ GSE (Fig. 5A) or $5^{\prime}$ GSE (Fig. 5B) elements.

As shown in Fig. 5A (lane 2), in vitro translated LRH-1 bound to the $3^{\prime}$ GSE-LH $\beta$ gene promoter region. The multiple band pattern observed is consistent with reports by other investigators studying LRH-1 action in non-gonadotrope genes (Galarneau et al. 1996, Li et al. 1998, Goodwin et al. 2000, Wang et al. 2001, Peng et al. 2003). Of note, the major complex migrated more

Figure 3 Transcriptional regulation of gonadotrope-specific genes by $\mathrm{LRH}-1$. (A) CV-1 cells were transfected with a CMV-driven $\mathrm{LRH}-1$ expression vector and the gonadotrope $\alpha$-subunit, $\mathrm{LH} \beta$-subunit, $\mathrm{FSH} \beta$-subunit or $\mathrm{GnRH}-\mathrm{R}$ promoters linked to a luciferase reporter vector. (B) CV-1 cells were transfected with region $-207 /+5$ of the rat $\mathrm{LH} \beta$ gene promoter and co-transfected with expression vectors encoding either $\mathrm{LRH}-1$ or SF-1. (C) CV-1 cells were transfected with the $\mathrm{LRH}-1$ expression vector and reporter constructs containing the rat $\mathrm{LH} \beta$ gene promoter as wild type or with mutations in the $3^{\prime} \mathrm{GSE}$ and/or $5^{\prime} \mathrm{GSE}$ cis-elements. (D) $L \beta T 2$ cells were transfected with region $-207 /+5$ of the rat LH $\beta$ gene promoter and co-transfected with expression vectors encoding either LRH-1 or SF-1. In all experiments, cells received a pSV- $\beta$-galactosidase vector to control for potential differences in transfection efficiency. Luciferase activity was corrected to $\beta$-galactosidase activity and the data expressed relative to expression in cells receiving the empty expression vector. Data represent the means \pm S.E.M. of a minimum of three independent experiments. ${ }^{*} P<0.001$. ${ }^{\#} P<0.05$ versus control. 

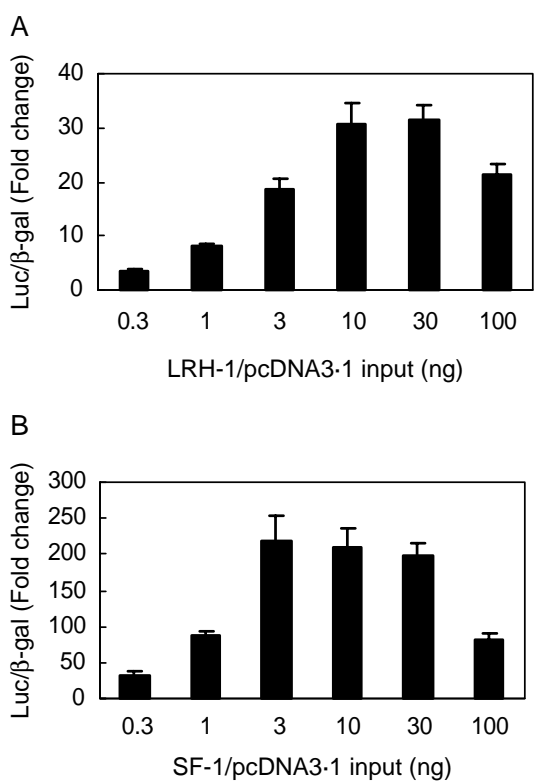

C

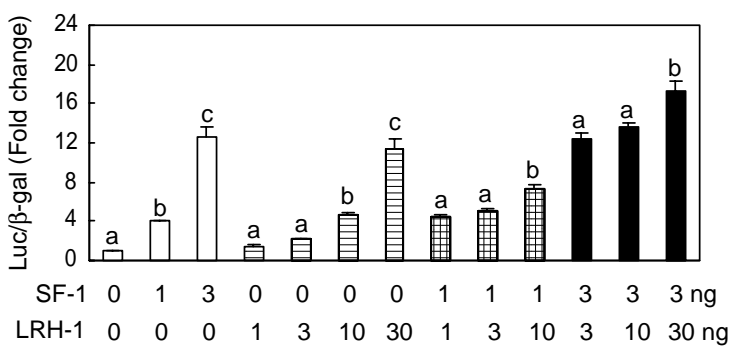

$\mathrm{LRH}-1$ and SF-1 plasmids input

Figure $4 \mathrm{LRH}-1$ and SF-1 dose-response curves and combined effects. CV-1 cells were transfected with region $-207 /+5$ of the rat $\mathrm{LH} \beta$ gene promoter and co-transfected with the indicated amount of expression vectors encoding either LRH-1 (A), SF-1 (B), or both transcription factors $(C)$. For the experiments shown in $(A)$ and $(B)$, the response to the expression vector was calculated relative to the response to an equivalent amount of the empty vector alone. $\ln (\mathrm{C})$, both treatment and control wells received a total of $33 \mathrm{ng}$ plasmid, with the amount of the plasmid encoding the transcription factors indicated in the figure. Addition of an increased amount of total vector blunted the fold-response to SF-1 or LRH-1 alone, but maintained a dose-response relationship. Bars in the same group with different letters differ significantly.

slowly than the SF-1 complex (lane 6), consistent with its larger predicted size based on sequence analysis and Western data (Fig. 2). The LRH-1 specific antisera were able to block formation of these complexes (lanes 4 and 5), while the SF-1 antibody had no effect (lane 3).

As previously reported, in vitro translated SF-1 also bound to the $3^{\prime} \mathrm{GSE}$ oligonucleotide region (lane 6), producing a complex, which was supershifted by the SF1-specific antibody (lane 7), but not by either of the LRH-1 antibodies (lanes 8 and 9). An essentially identical result was obtained using the $5^{\prime} \mathrm{GSE}$ region as the probe (Fig. 5B). These results demonstrate that LRH-1 is able to bind specifically to the LH $\beta$ gene promoter and that this binding is distinguishable from SF-1 binding by both migratory pattern and response to the addition of protein-specific antibodies.

\section{LRH-1 DNA-binding competition by unlabeled oligonucleotides}

In order to further confirm specificity of the LRH-1 interaction with the LH $\beta$ gene promoter, unlabeled oligonucleotides containing either the wild type or a mutated 3 GSE LH $\beta$ sequence were added to the EMSA mixture prior to electrophoresis (Fig. 6). Addition of excess wild type oligonucleotide nearly eliminated DNA-binding by LRH-1 (lane 2 vs lane 3), while the mutated oligonucleotide had no effect (lane 4). Similarly, only the wild type oligonucleotide blocked binding by SF-1 (lanes 6-8).

\section{Identification of nucleotides required for LRH-1 binding to the $3^{\prime}$ region}

In order to more precisely localize the nucleotides required for LRH-1 binding to the LH $\beta$ gene promoter, we generated a series of scanning mutations in the region of the $3^{\prime}$ GSE site (Fig. 7). The sequence of these oligonucleotides is depicted in Fig. 7A. These oligonucleotides were then used to generate ${ }^{32} \mathrm{P}$-labeled probes for analysis by EMSA. As shown in Fig. 7B, mutation of oligonucleotides at positions $-58 /-57$ and $-56 /-55$ completely eliminated LRH-1 DNA-binding, consistent with prior determination that these nucleotides form the 'core' sequence for interaction with a number of nuclear hormone receptors. Mutation at positions $-52 /-51$ substantially blunted the ability of LRH-1 to bind to the oligonucleotide probe. In contrast, mutations outside of these regions did not alter intensity of the LRH-1-DNA complex. In Fig. 7C, these oligonucleotide probes were tested for ability to bind to in vitro translated SF-1. The intensity of complex formation mirrored that observed for LRH-1, suggesting identical target sequences for both members of the NR5A nuclear receptor family.

\section{Endogenous LRH-1 binds to the LH $\beta$ gene promoter}

RT-PCR and Western analysis demonstrated the presence of LRH-1 transcripts and protein in pituitary cells and in gonadotrope cell lines (Figs 1 and 2). We next wanted to demonstrate that endogenous gonadotrope LRH-1 protein could bind to the rat LH $\beta$ gene promoter (Fig. 8). EMSA was performed using ${ }^{32} \mathrm{P}-$ labeled oligonucleotide probes that span either the $3^{\prime} \mathrm{GSE}$ (lanes 1-4) or $5^{\prime} \mathrm{GSE}$ (lanes 5-8) LH $\beta$ gene 
promoter sequences. In vitro translated LRH-1 (lanes 2 and 6) produced three complexes as observed in earlier experiments (Figs 5-7). L $\beta$ T2 nuclear extracts generated two complexes. Addition of an LRH-1 antibody blocked production of the upper band (lanes 4 and 8), demonstrating the presence of LRH-1 in this complex. The size of this complex is similar to the middle-sized

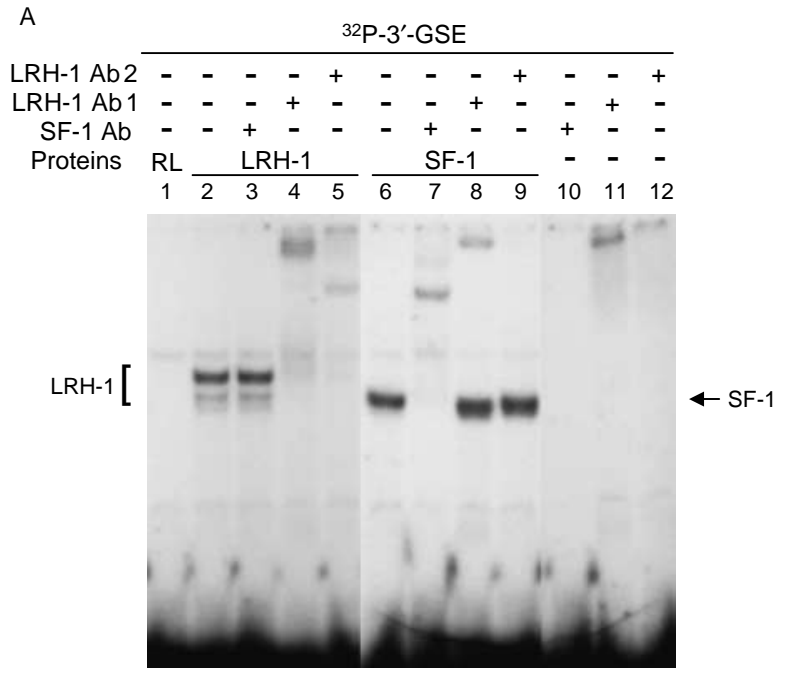

B

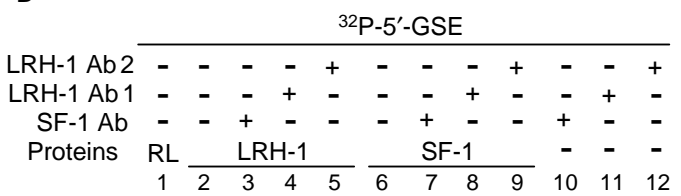

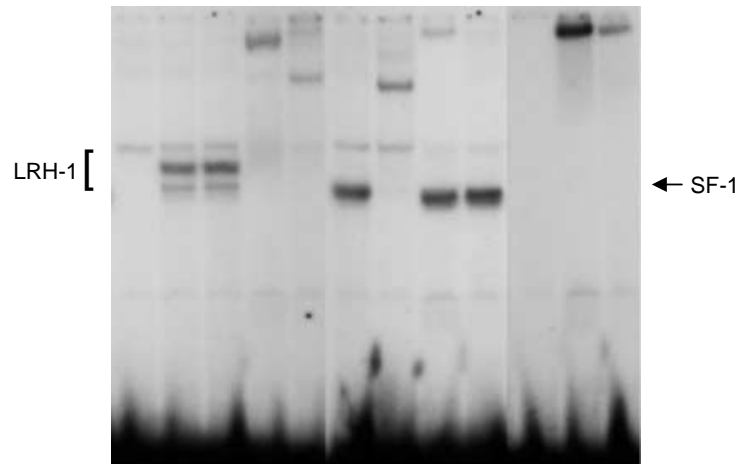

Figure $5 \mathrm{LRH}-1$ binds to the rat $\mathrm{LH} \beta$ gene promoter. (A) In vitro translated LRH-1 (lanes 2-5) and in vitro translated SF-1 (lanes $6-9)$ were added to a ${ }^{32} \mathrm{P}$-labeled oligonucleotide probe that spans nucleotide region -66 to -43 of the rat $\mathrm{LH} \beta$ gene promoter containing the $3^{\prime}$ GSE. An SF- 1 antiserum (lanes 3 and 7), LRH-1 antibody 1 (lanes 4 and 8) or LRH-1 antibody 2 (lanes 5 and 9) were added where indicated. In lanes 10-12, antibody was added to probe in the absence of protein. (B) Addition of proteins and/or antibodies to an oligonucleotide probe that spans region -134 to -113 of the rat $\mathrm{LH} \beta$ gene promoter containing the $5^{\prime}$ GSE. Lanes organized as in Fig. 5A. RL, reticulocyte lysate. product present in in vitro translated LRH-1 and may represent the same splice variant.

\section{Mutually exclusive interactions of LRH-1 and SF-1 on the LH $\beta$ gene promoter}

Both LRH-1 and SF-1 are classically believed to bind DNA as monomers. Nevertheless, both of these transcription factors are also known to interact with both co-activators and co-repressors (Crawford et al. 1997, 1998, Suzuki et al. 2002, Xu et al. 2003, 2004, Weck \& Mayo 2006). In addition, SF-1 has been shown to develop protein-protein interactions with another nuclear hormone receptor, the androgen receptor (Jorgensen \& Nilson 2001). We, therefore, wanted to determine whether there was evidence for direct interaction between LRH-1 and SF-1 on the LH $\beta$ gene promoter

EMSA was performed using a ${ }^{32} \mathrm{P}$-labeled oligonucleotide probe that spans the $3^{\prime}$ GSE-LH $\beta$ gene promoter sequence with addition of in vitro translated SF-1 and/or LRH-1 with total protein content adjusted by the addition of unprogrammed reticulolysate (Fig. 9). As observed previously, SF-1 produced a single complex, while LRH-1 produced three bands with the lower two bands overlapping the SF-1 complex. Addition of both LRH-1 and SF-1 generated an additive pattern; however, a higher order complex was not observed even with overexposure of the autoradiogram. Thus, LRH-1 and SF-1 appear to bind independently to the $3^{\prime}$ GSE-LH $\beta$ cis-element. The same results were obtained with the oligonucleotide probe spanning the $5^{\prime}$ GSE (data not shown).

\section{Discussion}

The orphan nuclear receptor, SF-1, has been clearly shown to be critical for the development and function of the hypothalamus, anterior pituitary gland, ovary, testes, and adrenal gland. More recent investigations have demonstrated co-expression of the closely related transcription factor, LRH-1, in the gonads and adrenal gland (Bookout et al. 2006). The results presented here strongly suggest that LRH-1 also co-exists with SF-1 in the gonadotrope cells of the anterior pituitary gland. Specifically, our data confirm LRH-1 mRNA expression in primary anterior pituitary cells as well as gonadotrope-derived cell lines and demonstrate, for the first time, the presence of LRH-1 protein in these cells. To our knowledge, our results are also the first to demonstrate that LRH-1 activates gonadotrope-specific gene promoter activity. In the rat $L H \beta$ gene, this response is achieved, at least in part, via binding to and activation of the previously characterized SF-1 ciselements (GSEs). 


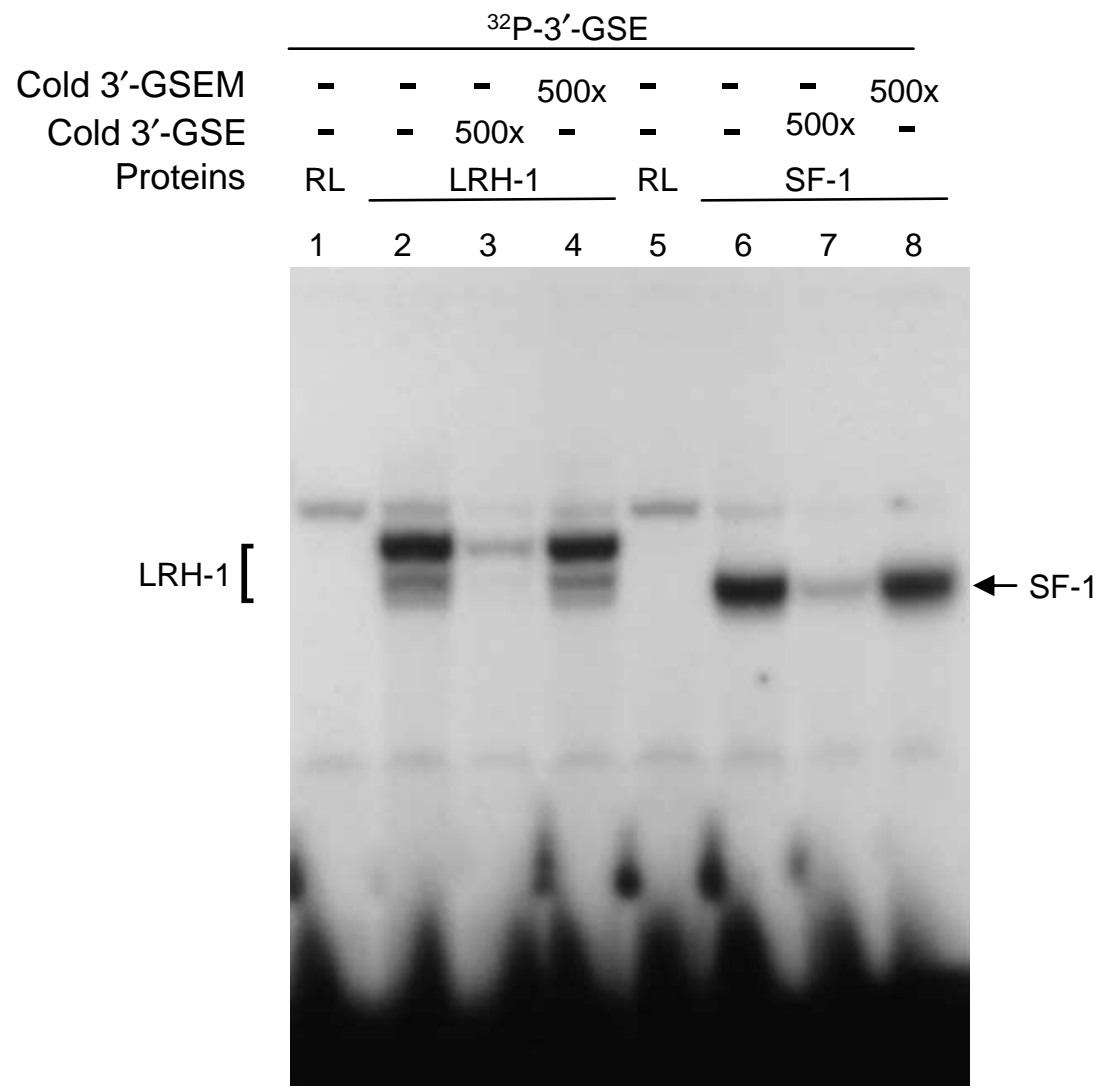

Figure 6 Specificity of LRH-1 binding to the wild type $\mathrm{LH} \beta$ gene promoter sequence. In vitro translated LRH-1 (lanes 2-4) and SF-1 (lanes 6-8) were added to a ${ }^{32} \mathrm{P}$-labeled oligonucleotide probe that contains the $3^{\prime}$ GSE-LH $\beta$ gene promoter sequence. Excess wild type (lanes 3 and 7 ) or mutated (M; lanes 4 and 8 ) oligonucleotide was added as indicated. $\mathrm{RL}$, reticulocyte lysate.

Our current study focuses on LRH-1 expression in primary anterior pituitary cells and in gonadotropederived cell lines. We have also detected LRH-1 mRNA expression in the somatolactotrope GH3 cell line (data not shown). As somatotropes and lactotropes comprise $50-80 \%$ and gonadotropes comprise at least $10 \%$ of the total secretory cells in the anterior pituitary, we predict that the majority of anterior pituitary cells express this protein. LRH-1 mRNA has also been identified in the posterior pituitary (Fig. 1A). It will be of interest in the future to perform co-localization studies in the rodent pituitary in order to fully define the cell types that express LRH-1.

LRH-1 transcript variants have been observed in both humans and mice, with both tissue-specific and developmentally stage-specific expression (Nitta et al. 1999, Gao et al. 2006). In the studies reported here, in vitro translated LRH-1 demonstrated a major product of approximately $64 \mathrm{kDa}$ on Western blot, consistent with the presence of a full-length product (Fig. 2). In contrast, a faster mobility product was detected from pituitary cells and gonadotrope cell lines, suggesting the presence of a truncation product in the pituitary.

Gao et al. (2006) have recently identified a truncated transcript of mouse LRH-1, termed mLRH-1v2, which may encode a protein of $57 \mathrm{kDa}$ compared with the fulllength protein at $64 \mathrm{kDa}$. Expressed in embryonic cells and a subset of adult tissues, this truncated transcript is directed by a promoter located downstream of the originally identified promoter (Gao et al. 2006). Based on this report, we designed several new primer pairs to evaluate the presence of the LRH-1 mRNA variants in the pituitary and in gonadotrope cell lines. The fulllength mouse LRH-1 mRNA (mLRH-1v1) was detected in the mouse liver (positive control), but not in the mouse primary pituitary, L $\beta$ T2, or $\alpha$ T3-1 cells (data not shown). These results indicate that the full length LRH1 protein is probably not expressed in the pituitary, consistent with the lack of full length LRH-1 protein observed by Western blot and EMSA analyses.

We also analyzed the presence of the short form variant described by Gao et al. (2006) as well as the expression of the common portion which contains the 
A

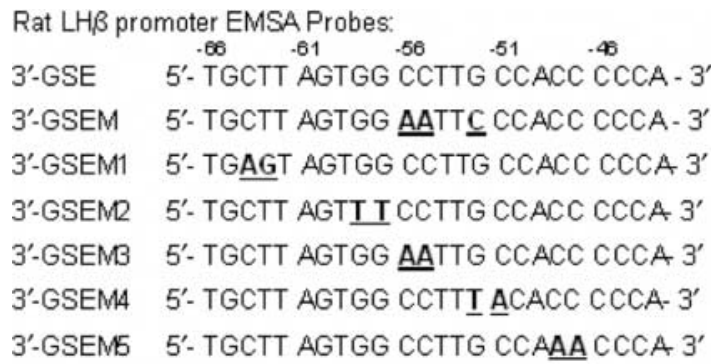

B

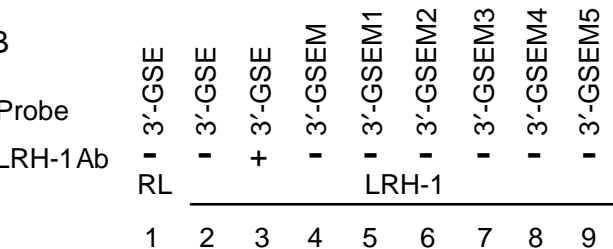

$\mathrm{LRH}-1$
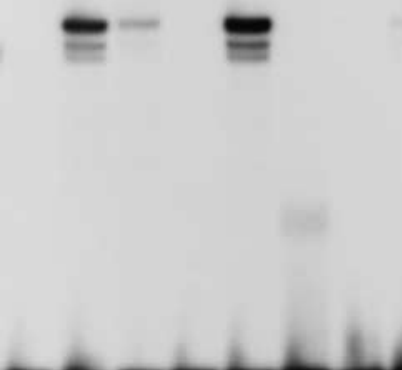

C
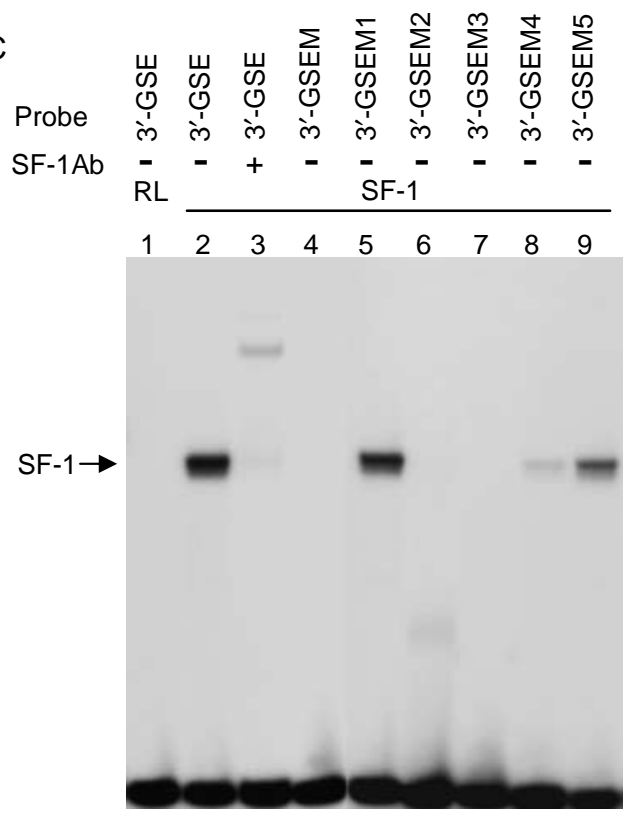

C-terminus found in both variants. The short form variant, which contains deletions in the $\mathrm{N}$-terminus, was not detected in pituitary cells. In contrast, the mRNA encoding the common portion was isolated from all cell types, indicating that the C-terminus is likely translated in the pituitary.

This conclusion is supported by the antibody experiments using antibodies that were directed against the common DNA binding domain (Ab1) or the hinge region to the C-terminus (Ab2). Using pituitary cell extracts, these antibodies were able to detect protein on Western blot and supershift DNAprotein complexes from pituitary cells, supporting the presence of these regions in the pituitary-derived LRH-1 variant.

Overall, we believe that these results imply that the anterior pituitary expresses a novel LRH-1 variant that differs from the mLRH-1v2 N-terminal mRNA sequence. This proposed pituitary variant would affect the integrity of the A/B domain but not the DNAbinding or ligand-binding domains. We would predict similar, although not necessarily identical, function of this pituitary LRH-1 variant, as Nitta and coworkers have reported that human CPF (a homologue of mouse LRH-1) and CPF variant 1, which differ in only the A/B region, induced CYP7A promoter activity to the same magnitude, suggesting that the hinge region and ligand-binding domain of CPF is important for its function (Nitta et al. 1999).

The co-expression of LRH-1 and SF-1 in a single cell type suggests that these closely related factors may exert distinct physiologic actions. Knock-out models for LRH1 and SF-1 support the concept that these factors have non-redundant functions. Unlike the SF-1 knockout animals, which are liveborn, mice lacking LRH-1 expression die at embryonic days $6 \cdot 5-7 \cdot 5$, demonstrating a critical role for LRH-1 in embryogenesis (Pare et al. 2004). Conversely, the gonads and adrenal glands are absent in SF-1 knockout mice, despite the presence of LRH-1 in these tissues (Luo et al. 1994, Sadovsky et al. 1995). Of note, transgenic mice containing a mutant GSE in the bovine LH $\beta$ gene promoter fail to express LH $\beta$ subunit (Keri \& Nilson 1996). Furthermore, initial characterization of SF-1 null animals did not detect gonadotropin expression. These results suggested that SF-1 and the GSE are both necessary and sufficient for gonadotropin $\beta$-subunit gene expression. However, it

Figure 7 Identification of nucleotides required for LRH-1 DNAbinding. (A) Oligonucleotide sequences used as probes for EMSA experiments. Mutated oligonucleotides are indicated by bold and underlining. (B) $\mathrm{LRH}-1$ complex formation in the presence of wild type or mutated (M) oligonucleotide probes. (C) SF-1 complex formation in the presence of wild type or mutated oligonucleotide probes. In lane 3 of both $\mathrm{B}$ and $\mathrm{C}$, the appropriate antibody was added to the reaction mixture to confirm the identity of the proteins present in the complexes. 


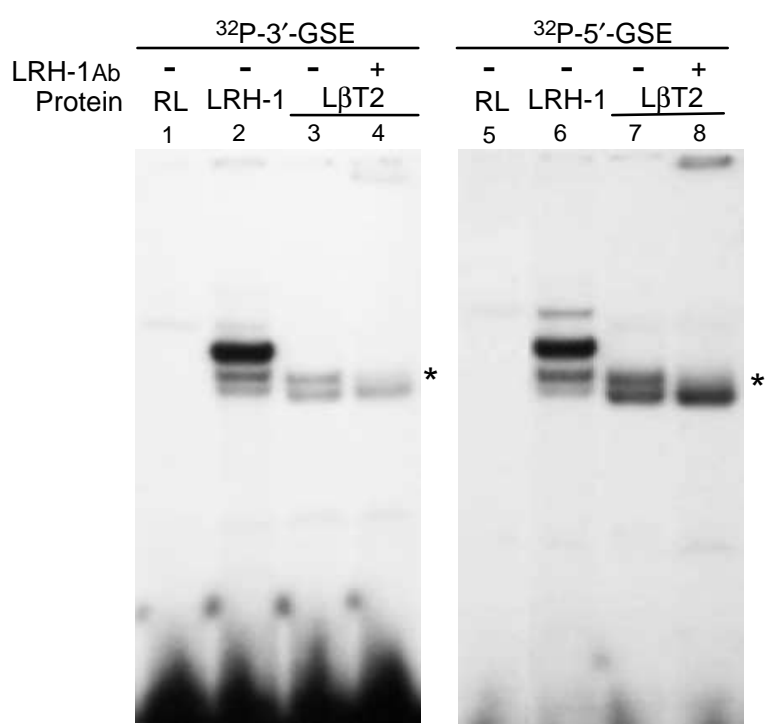

Figure 8 Endogenous $\mathrm{LRH}-1$ binds to the $\mathrm{LH} \beta$ gene promoter. EMSA was performed using ${ }^{32} \mathrm{P}$-labeled oligonucleotide probes that span either the $3^{\prime}$ GSE (left panel) or $5^{\prime}$ GSE (right panel) LH $\beta$ gene promoter sequences. The proteins added to this probe were unprogrammed reticulocyte lysate (RL; lanes 1 and 5), in vitro translated LRH-1 (lanes 2 and 6 ), or nuclear extracts from the gonadotrope-derived L $\beta$ T2 cell line (lanes 3, 4, 7, and 8). The asterisks indicate loss of complex formation with addition of a specific LRH-1 antibody (lanes 4 and 8).

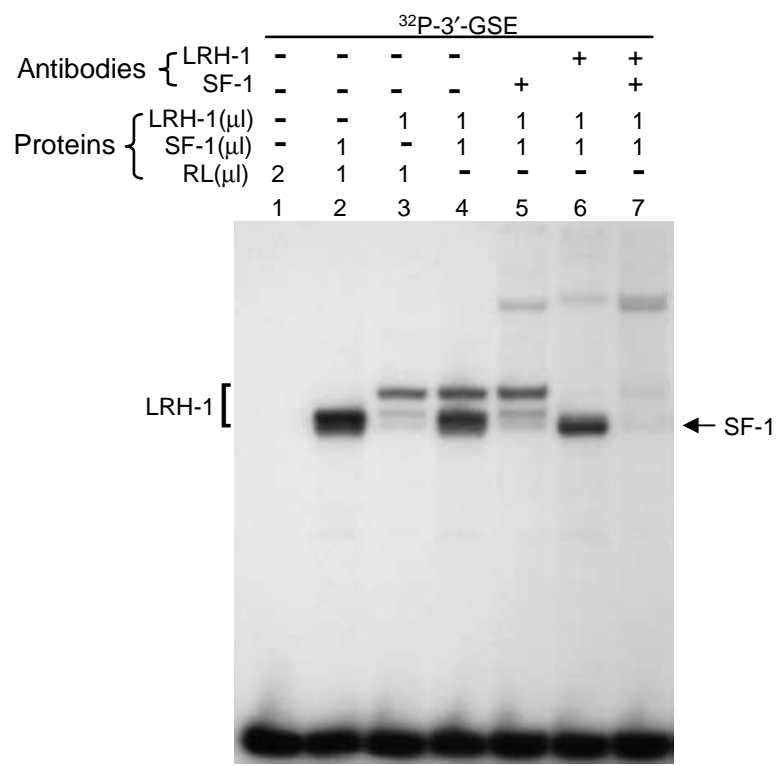

Figure $9 \mathrm{LRH}-1$ and SF-1 bind independently to the $\mathrm{LH} \beta$ gene promoter. EMSA was performed using a ${ }^{32} \mathrm{P}$-labeled oligonucleotide probe that spans the $3^{\prime}$ GSE-LH $\beta$ gene promoter sequence. Complex formation was analyzed in the presence of reticulolysate (RL; lane 1), SF-1 (lane 2), LRH-1 (lane 3), or both $\mathrm{LRH}-1$ and SF-1 (lanes 4-7). An SF-1 antibody (lane 5), LRH-1 antibody (lane 6) or both antibodies (lane 7) were added to the reaction mixture as indicated. was subsequently reported that GnRH treatment of SF-1 disrupted mice restored gonadotropin expression in 4 of 5 animals tested (Ikeda et al. 1995, Shinoda et al. 1995). These observations suggest that another factor, perhaps LRH-1, is able to support gonadotropin gene expression in the absence of SF-1 and this function is dependent on an intact GSE element, now known to bind LRH-1 in addition to SF-1.

LRH-1-mediated transcriptional activation appears to occur via previously identified SF-1 binding sites in the genes which have been studied thus far, including our studies of the gonadotropin LH $\beta$-subunit gene (Wang et al. 2001, Clyne et al. 2002, Peng et al. 2003, Weck \& Mayo 2006). Therefore, differential function by these two transcription factors must be achieved by mechanisms other than use of alternative cis-elements. Multiple possible mechanisms may be postulated. For example, LRH-1 and SF-1 may be differentially regulated by distinct DNA-regulatory elements within their own promoters or by differential binding to co-activators and co-repressors. Alternatively, LRH-1 and $S F-1$ gene expression and functional activity may differ depending on hormonal milieu, activation of intracellular signaling systems, or differences in ligandbinding.

Transcriptional regulation of LRH-1 and SF-1 gene expression has been shown to be mediated via differing cis-elements. LRH-1 is regulated via three GATA elements, as well as DNA-regulatory regions recognized by pancreatic-duodenal homeobox 1 and Nkx homeodomain proteins (Pare et al. 2001, Annicotte et al. 2003). In contrast, the SF-1 gene promoter contains a functional $\mathrm{E}$ box, CCAAT box and Sp1/Sp3 sites (Woodson et al. 1997, Scherrer et al. 2002). This disparity in regulatory elements within the LRH-1 and SF-1 gene promoters may allow for both tissue-specific expression as well as differing levels of expression within single cells.

LRH-1 and SF-1 transcriptional activity may be differentially affected by the presence of various coactivators and corepressors within the nucleus. The anterior pituitary, for example, expresses the inhibitory cofactors DAX-1 (dosage-sensitive sex reversal adrenal hypoplasia congenita critical region on the $\mathrm{X}$, gene 1) and small heterodimer partner (SHP; Ikeda et al. 1996). SHP mRNA has been detected in anterior pituitary samples (data not shown). DAX-1 inhibits both SF-1 and LRH-1 transcriptional activity, while SHP is believed to be specific to LRH-1, thus providing another mechanism for divergent function.

SF-1 has been shown to activate LH $\beta$ gene promoter activity alone and in synergy with other transcription factors, including pituitary homeobox 1 (Pitx1) and early growth response protein 1 (Egr-1; Halvorson $e t$ al. 1998, Tremblay \& Drouin 1999, Kaiser et al. 2000, Quirk et al. 2001). Pitx1 is likely to be important to pituitary 
development, while Egr-1 is highly regulated by GnRH and by both the protein kinase $\mathrm{C}$ and protein kinase $\mathrm{A}$ second messenger signaling systems. Currently, it is not known whether LRH-1 interacts with additional transcription factors within the pituitary, although this will be an important line of study for future investigations.

Although both SF-1 and LRH-1 have been categorized classically as 'orphan' nuclear receptors, it has recently been demonstrated that phosphatidyl inositols are likely ligands for mouse and human LRH-1 (Krylova et al. 2005). Further, characterization of the specific biochemical subtypes which bind to these receptors is lacking. Interestingly, perhaps due to a mutation at amino acid position 440, mouse LRH-1 does not require ligand for activity. Thus, subtle differences in ligand or in the requirement for ligand could allow for yet another level of differential function.

Phosphorylation of either LRH-1 or SF-1 alters the functional activity of these nuclear receptors. SF-1 has been shown to be phosphorylated by both the mitogen activated protein (MAP) kinase and protein kinase A systems (Hammer et al. 1999, Desclozeaux et al. 2002, Fowkes et al. 2003). Lee et al. (2006) likewise demonstrated phosphorylation of LRH-1 by MAP kinase. Interestingly, they also observed the presence of extracellular signal-regulated kinases (ERK) phosphorylation sites in LRH-1 that were conserved across species but lacking in SF-1 gene sequence.

Studies in the ovary have demonstrated divergent hormonal regulation of LRH-1 and SF-1. SF-1 mRNA levels in granulosa cells are markedly induced by treatment with either estradiol or FSH. In contrast, LRH-1 is responsive only to FSH treatment (Falender et al. 2003).

In a recent report, Weck \& Mayo (2006) provide perhaps the strongest indication that LRH-1 and SF-1 can have distinct functions despite interaction with a common cis-element. Their data suggest that hormonal or pharmacologic activation of intracellular signaling pathways differentially alter both DNA-binding affinity and transactivation efficacy of LRH-1 and SF-1. Specifically, they demonstrate that forskolin treatment leads to replacement of SF-1 by LRH-1 on the inhibin $\alpha$-subunit gene in granulosa cells. Thus, the forskolinmediated increase in $\alpha$-inhibin promoter activity is achieved through a switch in NR5A DNA-binding in conjunction with recruitment of cAMP response element binding protein. It is possible that variations in physiologic status result in alternative recruitment of LRH-1 or SF-1 to the GSE sites in the $L H \beta$ gene.

Based on our data, SF-1 is likely more potent than LRH-1 in activating basal LH $\beta$ gene promoter activity (Fig. 3D). As these two factors bind the promoter independently as monomers (Fig. 9), we had predicted that the co-expression of high levels of LRH-1, the weaker factor, might blunt the SF-1 response.
Unexpectedly, the addition of both factors was mildly additive (Fig. 4C). This result suggests the presence of a complex recruitment pattern for LRH-1 relative to SF-1 on the LH $\beta$ gene promoter, as described for the inhibin- $\alpha$ subunit.

In summary, our data demonstrate the presence of $L R H-1$ gene expression in the gonadotrope subpopulation of the anterior pituitary gland. Furthermore, our results localize LRH-1-mediated stimulation of LH $\beta$ gene promoter activity to the previously described SF-1 cis-elements. These data strongly support a role for LRH-1 in the regulation of gonadotrope function. We propose that LRH-1 and SF-1 may provide both overlapping and distinct functions in the anterior pituitary gland.

\section{Acknowledgements}

This work was supported by R01 HD38089 (to L M $\mathrm{H})$. The authors declare that there is no conflict of interest that would prejudice the impartiality of this scientific work.

\section{References}

Annicotte JS, Fayard E, Swift GH, Selander L, Edlund H, Tanaka T, Kodama T, Schoonjans K \& Auwerx J 2003 Pancreatic-duodenal homeobox 1 regulates expression of liver receptor homolog 1 during pancreas development. Molecular and Cellular Biology 23 6713-6724.

Barnhart KM \& Mellon PL 1994 The orphan nuclear receptor, steroidogenic factor-1, regulates the glycoprotein hormone alphasubunit gene in pituitary gonadotropes. Molecular Endocrinology 8 878-885.

Bookout AL, Jeong Y, Downes M, Yu RT, Evans RM \& Mangelsdorf DJ 2006 Anatomical profiling of nuclear receptor expression reveals a hierarchical transcriptional network. Cell 126 789-799.

Clyne CD, Speed CJ, Zhou J \& Simpson ER 2002 Liver receptor homologue-1 (LRH-1) regulates expression of aromatase in preadipocytes. Journal of Biological Chemistry 277 20591-20597.

Clyne CD, Kovacic A, Speed CJ, Zhou J, Pezzi V \& Simpson ER 2004 Regulation of aromatase expression by the nuclear receptor LRH-1 in adipose tissue. Molecular and Cellular Endocrinology 215 39-44.

Crawford PA, Polish JA, Ganpule G \& Sadovsky Y 1997 The activation function-2 hexamer of steroidogenic factor-1 is required, but not sufficient for potentiation by SRC-1. Molecular Endocrinology 11 1626-1635.

Crawford PA, Dorn C, Sadovsky Y \& Milbrandt J 1998 Nuclear receptor DAX-1 recruits nuclear receptor corepressor N-CoR to steroidogenic factor 1. Molecular and Cellular Biology 18 2949-2956.

Desclozeaux M, Krylova IN, Horn F, Fletterick RJ \& Ingraham HA 2002 Phosphorylation and intramolecular stabilization of the ligand binding domain in the nuclear receptor steroidogenic factor 1 . Molecular and Cellular Biology 22 7193-7203.

Falender AE, Lanz R, Malenfant D, Belanger L \& Richards JS 2003 Differential expression of steroidogenic factor-1 and FTF/LRH-1 in the rodent ovary. Endocrinology 144 3598-3610.

Fowkes RC, Desclozeaux M, Patel MV, Aylwin SJ, King P, Ingraham HA \& Burrin JM 2003 Steroidogenic factor-1 and the gonadotrope-specific element enhance basal and pituitary adenylate cyclase-activating 
polypeptide-stimulated transcription of the human glycoprotein hormone alpha-subunit gene in gonadotropes. MolecularEndocrinology 17 2177-2188.

Galarneau L, Pare JF, Allard D, Hamel D, Levesque L, Tugwood JD, Green S \& Belanger L 1996 The alphal-fetoprotein locus is activated by a nuclear receptor of the Drosophila FTZ-F1 family. Molecular and Cellular Biology 16 3853-3865.

Gao DM, Wang LF, Liu J, Kong YY, Wang Y \& Xie YH 2006 Expression of mouse liver receptor homologue 1 in embryonic stem cells is directed by a novel promoter. FEBS Letter $\mathbf{5 8 0}$ 1702-1708.

Goodwin B, Jones SA, Price RR, Watson MA, McKee DD, Moore LB, Galardi C, Wilson JG, Lewis MC, Roth ME et al. 2000 A regulatory cascade of the nuclear receptors FXR, SHP-1, and LRH-1 represses bile acid biosynthesis. Molecular Cell 6 517-526.

Haisenleder DJ, Yasin M, Dalkin AC, Gilrain J \& Marshall JC 1996 $\mathrm{GnRH}$ regulates steroidogenic factor-1 (SF-1) gene expression in the rat pituitary. Endocrinology 137 5719-5722.

Halvorson LM, Kaiser UB \& Chin WW 1996 Stimulation of luteinizing hormone beta gene promoter activity by the orphan nuclear receptor, steroidogenic factor-1. Journal of Biological Chemistry 271 6645-6650.

Halvorson LM, Ito M, Jameson JL \& Chin WW 1998 Steroidogenic factor-1 and early growth response protein 1 act through two composite DNA binding sites to regulate luteinizing hormone beta-subunit gene expression. Journal of Biological Chemistry 273 14712-14720.

Hammer GD, Krylova I, Zhang Y, Darimont BD, Simpson K, Weigel NL \& Ingraham HA 1999 Phosphorylation of the nuclear receptor SF-1 modulates cofactor recruitment: integration of hormone signaling in reproduction and stress. Molecullar Cell 3 521-526.

Hinshelwood MM, Repa JJ, Shelton JM, Richardson JA, Mangelsdorf DJ \& Mendelson CR 2003 Expression of LRH-1 and SF-1 in the mouse ovary: localization in different cell types correlates with differing function. Molecular and Cellular Endocrinology 207 39-45.

Horn F, Windle JJ, Barnhart KM \& Mellon PL 1992 Tissue-specific gene expression in the pituitary: the glycoprotein hormone alphasubunit gene is regulated by a gonadotrope-specific protein. Molecular and Cellular Biology 12 2143-2153.

Huang HJ, Sebastian J, Strahl BD, Wu JC \& Miller WL 2001 Transcriptional regulation of the ovine follicle-stimulating hormone-beta gene by activin and gonadotropin-releasing hormone $(\mathrm{GnRH})$ : involvement of two proximal activator protein-1 sites for GnRH stimulation. Endocrinology 142 2267-2274.

Ikeda Y, Luo X, Abbud R, Nilson JH \& Parker KL 1995 The nuclear receptor steroidogenic factor 1 is essential for the formation of the ventromedial hypothalamic nucleus. Molecular Endocrinology 9 478-486.

Ikeda Y, Swain A, Weber TJ, Hentges KE, Zanaria E, Lalli E, Tamai KT, Sassone-Corsi P, Lovell-Badge R, Camerino G et al. 1996 Steroidogenic factor 1 and Dax-1 colocalize in multiple cell lineages: potential links in endocrine development. Molecular Endocrinology 10 1261-1272.

Jacobs SB, Coss D, McGillivray SM \& Mellon PL 2003 Nuclear factor Y and steroidogenic factor 1 physically and functionally interact to contribute to cell-specific expression of the mouse Folliclestimulating hormone-beta gene. Molecular Endocrinology 17 $1470-1483$.

Jeong KH, Chin WW \& Kaiser UB 2004 Essential role of the homeodomain for pituitary homeobox 1 activation of mouse gonadotropin-releasing hormone receptor gene expression through interactions with c-Jun and DNA. Molecular and Cellular Biology 24 6127-6139.

Jorgensen JS \& Nilson JH 2001 AR suppresses transcription of the LH beta subunit by interacting with steroidogenic factor-1. Molecular Endocrinology 15 1505-1516.

Kaiser UB, Halvorson LM \& Chen MT 2000 Sp1, steroidogenic factor 1 (SF-1), and early growth response protein 1 (egr-1) binding sites form a tripartite gonadotropin-releasing hormone response element in the rat luteinizing hormone-beta gene promoter: an integral role for SF-1. Molecular Endocrinology 14 1235-1245.

Keri RA \& Nilson JH 1996 A steroidogenic factor-1 binding site is required for activity of the luteinizing hormone beta subunit promoter in gonadotropes of transgenic mice. Journal of Biological Chemistry 271 10782-10785.

Keri RA, Bachmann DJ, Behrooz A, Herr BD, Ameduri RK, Quirk CC \& Nilson JH 2000 An NF-Y binding site is important for basal, but not gonadotropin-releasing hormone-stimulated, expression of the luteinizing hormone beta subunit gene. Journal of Biological Chemistry 275 13082-13088.

Krylova IN, Sablin EP, Moore J, Xu RX, Waitt GM, MacKay JA, Juzumiene D, Bynum JM, Madauss K, Montana V et al. 2005 Structural analyses reveal phosphatidyl inositols as ligands for the NR5 orphan receptors SF-1 and LRH-1. Cell 120 343-355.

Kudo T \& Sutou S 2006 Chicken LRH-1 gene is transcribed from multiple promoters in steroidogenic organs. Gene 367 38-45.

Lambard S, Silandre D, Delalande C, Denis-Galeraud I, Bourguiba S \& Carreau S 2005 Aromatase in testis: expression and role in male reproduction. Journal of Steroid Biochemistry and Molecular Biology 95 63-69.

Lee SL, Sadovsky Y, Swirnoff AH, Polish JA, Goda P, Gavrilina G \& Milbrandt J 1996 Luteinizing hormone deficiency and female infertility in mice lacking the transcription factor NGFI-A (Egr-1). Science 273 1219-1221.

Lee YK, Choi YH, Chua S, Park YJ \& Moore DD 2006 Phosphorylation of the hinge domain of the nuclear hormone receptor LRH-1 stimulates transactivation. Journal of Biological Chemistry 281 $7850-7855$.

Li M, Xie YH, Kong YY, Wu X, Zhu L \& Wang Y 1998 Cloning and characterization of a novel human hepatocyte transcription factor, $\mathrm{hB1F}$, which binds and activates enhancer II of hepatitis B virus. Journal of Biological Chemistry 273 29022-29031.

Lu TT, Makishima M, Repa JJ, Schoonjans K, Kerr TA, Auwerx J \& Mangelsdorf DJ 2000 Molecular basis for feedback regulation of bile acid synthesis by nuclear receptors. Molecular Cell 6 507-515.

Luo X, Ikeda Y \& Parker KL 1994 A cell-specific nuclear receptor is essential for adrenal and gonadal development and sexual differentiation. Cell 77 481-490.

Nitta M, Ku S, Brown C, Okamoto AY \& Shan B 1999 CPF: an orphan nuclear receptor that regulates liver-specific expression of the human cholesterol 7alpha-hydroxylase gene. PNAS 96 6660-6665.

Nordeen SK 1988 Luciferase reporter gene vectors for analysis of promoters and enhancers. Biotechniques 6 454-458.

Norwitz ER, Xu S, Xu J, Spiryda LB, Park JS, Jeong KH, McGee EA \& Kaiser UB 2002 Direct binding of AP-1 (Fos/Jun) proteins to a SMAD binding element facilitates both gonadotropin-releasing hormone $(\mathrm{GnRH})$ - and activin-mediated transcriptional activation of the mouse GnRH receptor gene. Journal of Biological Chemistry 277 37469-37478.

Pare JF, Roy S, Galarneau L \& Belanger L 2001 The mouse fetoprotein transcription factor (FTF) gene promoter is regulated by three GATA elements with tandem $\mathrm{E}$ box and Nkx motifs, and FTF in turn activates the Hnf3beta, Hnf4alpha, and Hnflalpha gene promoters. Journal of Biological Chemistry 276 13136-13144.

Pare JF, Malenfant D, Courtemanche C, Jacob-Wagner M, Roy S, Allard D \& Belanger L 2004 The fetoprotein transcription factor (FTF) gene is essential to embryogenesis and cholesterol homeostasis and is regulated by a DR4 element. Journal of Biological Chemistry $\mathbf{2 7 9}$ 21206-21216.

Peng N, Kim JW, Rainey WE, Carr BR \& Attia GR 2003 The role of the orphan nuclear receptor, liver receptor homologue-1, in the regulation of human corpus luteum 3beta-hydroxysteroid dehydrogenase type II. Journal of Clinical Endocrinology and Metabolism 88 6020-6028.

Pezzi V, Sirianni R, Chimento A, Maggiolini M, Bourguiba S, Delalande C, Carreau S, Ando S, Simpson ER \& Clyne CD 2004 Differential 
expression of steroidogenic factor-1/adrenal 4 binding protein and liver receptor homolog-1 (LRH-1)/fetoprotein transcription factor in the rat testis: LRH-1 as a potential regulator of testicular aromatase expression. Endocrinology 145 2186-2196.

Pincas H, Amoyel K, Counis R \& Laverriere JN 2001 Proximal cis-acting elements, including steroidogenic factor 1 , mediate the efficiency of a distal enhancer in the promoter of the rat gonadotropin-releasing hormone receptor gene. Molecular Endocrinology 15 319-337.

Quirk CC, Lozada KL, Keri RA \& Nilson JH 2001 A single Pitx1 binding site is essential for activity of the LHbeta promoter in transgenic mice. Molecular Endocrinology 15 734-746.

Sadovsky Y, Crawford PA, Woodson KG, Polish JA, Clements MA, Tourtellotte LM, Simburger K \& Milbrandt J 1995 Mice deficient in the orphan receptor steroidogenic factor 1 lack adrenal glands and gonads but express $\mathrm{P} 450$ side-chain-cleavage enzyme in the placenta and have normal embryonic serum levels of corticosteroids. PNAS 92 10939-10943.

Scherrer SP, Rice DA \& Heckert LL 2002 Expression of steroidogenic factor 1 in the testis requires an interactive array of elements within its proximal promoter. Biology of Reproduction 67 1509-1521.

Shinoda K, Lei H, Yoshii H, Nomura M, Nagano M, Shiba H, Sasaki H, Osawa Y, Ninomiya Y, Niwa O et al. 1995 Developmental defects of the ventromedial hypothalamic nucleus and pituitary gonadotroph in the Ftz-F1 disrupted mice. Developmental Dynamics 204 22-29.

Sirianni R, Seely JB, Attia G, Stocco DM, Carr BR, Pezzi V \& Rainey WE 2002 Liver receptor homologue-1 is expressed in human steroidogenic tissues and activates transcription of genes encoding steroidogenic enzymes. Journal of Endocrinology 174 R13-R17.

Solomon IH, Hager JM, Safi R, McDonnell DP, Redinbo MR \& Ortlund EA 2005 Crystal structure of the human LRH-1 DBD-DNA complex reveals Ftz-F1 domain positioning is required for receptor activity. Journal of Molecular Biology 354 1091-1102.
Suzuki T, Kasahara M, Yoshioka H, Umesono K \& Morohashi K 2002 LXXLL motifs in Dax-1 have target specificity for the orphan nuclear receptors Ad4BP/SF-1 and LRH-1. Endocrine Research 28537.

Tremblay JJ \& Drouin J 1999 Egr-1 is a downstream effector of GnRH and synergizes by direct interaction with Ptx1 and SF-1 to enhance luteinizing hormone beta gene transcription. Molecular and Cellular Biology 19 2567-2576.

Wang ZN, Bassett M \& Rainey WE 2001 Liver receptor homologue-1 is expressed in the adrenal and can regulate transcription of 11 betahydroxylase. Journal of Molecular Endocrinology 27 255-258.

Weck J \& Mayo KE 2006 Switching of NR5A proteins associated with the inhibin alpha-subunit gene promoter after activation of the gene in granulosa cells. Molecular Endocrinology 20 1090-1103.

de Wet JR, Wood KV, DeLuca M, Helinski DR \& Subramani S 1987 Firefly luciferase gene: structure and expression in mammalian cells. Molecular and Cellular Biology 7 725-737.

Woodson KG, Crawford PA, Sadovsky Y \& Milbrandt J 1997 Characterization of the promoter of SF-1, an orphan nuclear receptor required for adrenal and gonadal development. Molecular Endocrinology 11 117-126.

Xu PL, Kong YY, Xie YH \& Wang Y 2003 Corepressor SMRT specifically represses the transcriptional activity of orphan nuclear receptor hB1F/hLRH-1. Sheng Wu Hua Xue Yu Sheng Wu Wu Li Xue Bao (Shanghai) 35 897-903.

Xu PL, Liu YQ, Shan SF, Kong YY, Zhou Q, Li M, Ding JP, Xie YH \& Wang Y 2004 Molecular mechanism for the potentiation of the transcriptional activity of human liver receptor homolog 1 by steroid receptor coactivator-1. Molecular Endocrinology 18 1887-1905.

Received in final form 27 October 2006

Accepted 20 November 2006 